\title{
PREDIKSI CURAH HUJAN DENGAN METODE BACKPROPAGATION DAN REGERESI LINEAR DALAM PENENTUAN JADWAL TANAM PADI
}

\author{
Andi Nurfadly \\ Keamanan Sistem Informasi, Politeknik Nusantara Makassar \\ Email : nurfadlyandi@gmail.com
}

\begin{abstract}
ABSTRAK
Ketergantungan yang sangat tinggi terhadap curah hujan menjadikan lahan sawah tadah hujan memiliki periode tanam yang terbatas. Sementara curah hujan itu sendiri sangat dipengaruhi oleh perubahan iklim. Makalah ini menyajikan hasil analisis tentang hubungan perubahan iklim yang dinyatakan dengan perubahan suhu, curah hujan dan konsentrasi CO2 terhadap produksi padi di lahan sawah tadah hujan, karna itu untuk mendapatkan hasil terbaik, tanaman padi mambutuhkan unsur penunjang, salah satunya adalah curah hujan. Olehnya karena itu petani sangat penting untuk memprediksi curah hujan agar jadwal tanam padi tepat, sehingga dibutuhkan satu aplikasi yang dapat membantu para petani dalam memprediksi curah hujan. Rancangan ini menggunakan teknik peramalan dengan jaringan saraf tiruan (JST) untuk prediksi keadaan curah hujan. Hasil prediksi curah hujan dan data produktivitas padi digunakan untuk penentuan jadwal tanam padi dengan menggunakan regresi linear. Berdasarkan penelitian yang telah dilakukan, maka dapat diambil kesimpulan antara lain Hasil prediksi jadwal tanam padi maksimum diperoleh pada bulan dengan memilih nilai tertinggi, Dan ditentukan jadwal tanam yang baik adalah pada bulan Mei.Pada prediksi curah hujan diperoleh nilai MSE sebesar 14,08333 dan nilai RMSE adalah sebesar 3,752777, Dinyatakan sangat baik sesuai dengan standar yang telah ditentukan.Perubahan pola curah hujan sangat berpengaruh pada hasil produksi padi disuatu daerah terutama dengan lahan sawah yang hanya mengandalkan hujan (Sawah tadah hujan).
\end{abstract}

Kata Kunci: Curah Hujan, Backpropagation, Regeresi Linear, Jadwal Tanam, Padi.

\begin{abstract}
Very high dependence on rainfall makes rainfed paddy fields have a limited planting period. While rainfall itself is strongly influenced by climate change. This paper presents the results of an analysis of the relationship of climate change expressed by changes in temperature, rainfall and $\mathrm{CO} 2$ concentration on rice production in rain-fed rice fields, because of that to get the best results, rice plants add supporting elements, one of which is rainfall. Therefore, because it is very important for farmers to predict rainfall so that the rice planting schedule is right, so we need an application that can help farmers in predicting rainfall. This design uses forecasting techniques with artificial neural networks (ANN) to predict rainfall conditions. The results of rainfall prediction and rice productivity data are used to determine the rice planting schedule using linear regression. Based on the research that has been done, the conclusions can be drawn, among others, the predicted results of the maximum rice planting schedule obtained in the month by selecting the highest value, and determined a good planting schedule is in May. On the prediction of rainfall, the MSE value of 14.08333 and the value of RMSE is 3.752777,
\end{abstract}


expressed very well in accordance with predetermined standards. Changes in rainfall patterns are very influential on the yield of rice production in an area, especially with paddy fields that only rely on rain (rainfed lowland).

Keywords: Rainfall, Backpropagation, Linear Regression, Planting Schedule, Rice.

\section{PENDAHULUAN}

Untuk mendapatkan hasil terbaik dari proses menanam membutuhkan beberapa unsur penunjang diantaranya curah hujan, sinar matahari, suhu, kelembaban, angin, dan masih banyak faktor pendukung lainnya walaupun fungsinya hanya sedikit. Namun dari sekian banyak faktor yang dibutuhkan untuk mendapatkan hasil tanaman yang baik, curah hujan merupakan salah satu faktor terpenting yang harus diperhatikan oleh para petani

Beberapa permasalahan yang dibahas penelitian ini adalah:

1. Bagaimana memodelkan prediksi curah hujan dengan menggunakan jaringan saraf tiruan?

2. Bagaimana memodelkan jadwal tanam padi berdasarkan hasil prediksi curah hujan dengan metode regresi linear?

3. Bagaimana menentukan jadwal penanaman padi yang baik untuk mendapatkan hasil produksi padi yang maksimal.

Penelitian ini bertujuan Menunjukkan korelasi antara curah hujan terhadap jadawal tanam padi dengan jaringan saraf tiruan, memprediksi jadwal tanam dan padi dengan menggunakan metode regresi linear, menentukan jadwal tanam padi yang baik untuk mendapatkan hasil produksi padi yang maksimal.

\section{LANDASAN TEORI}

Kajian literatur mencakup kajian teori dan hasil penelitian terdahulu dituliskan sebagai bagian terpisah.

Penelitian ini berjudul "pengaruh perubahan iklim terhadap produksi padi di lahan tadah hujan"Tujuan peneilitian ini meningkatkan kualitas produksi padi engan memperhatikan dampak perubahan iklim terhadap produksi padi di lahan sawah tadah hujan dengan model simulasi tanaman DSSAT. Lokasi penelitian yaitu Jakenan dan Ngale. Skenario perubahan iklim yang digunakan dalam penelitian ini merupakan hasil analisis menggunakan model CoordinatedClimate-Crop Modeling Program (C3MP) Sensitivity test Versi 2.0. Uji sensitivitas C3MPdilakukan dengan menyesuaikan kondisi iklim historis untuk mencerminkan perubahan o suhu, presipitasi, dan $\mathrm{CO}$. Hasil penelitian menunjukkan bahwa Perubahan suhu 0,5 C dan konsentrasi CO 537 ppm 22 masih meningkatkan produksi 2,2 hingga 502,5 $\mathrm{kg} /$ ha di Jakenan dan 15,9 hingga 507,7 $\mathrm{kg} / \mathrm{ha}$ di Ngale yang terjadi o hampir di setiap Bulan mulai Januari-Desember. Perubahan suhu $1 \mathrm{C}$ dan konsentrasi $\mathrm{CO}$ 403 ppm secara umum masih 2 meningkatkan hasil tetapi hanya terjadi pada bulan-bulan tertentu yaitu sebesar 57,4 hingga $366,2 \mathrm{~kg} / \mathrm{ha}$ di Jakenan dan 21,9 - 320,4 kg/ha di Ngale (Woro Estiningtyas dan Muhammad Syakir 2017).

“AplikasiI model prediksi curah hujan pada dua sentra produksi padi di Jawa 
Barat". Tujuan penelitian adalah meningkatkan hasil produksi tanaman padi padah sawah tadah hujan dengan menyusun model prediksi curah hujan menggunakan teknik analisis jaringan syaraf tiruan, mengaplikasikan model prediksi di sentra produksi padi, dan membandingkan model prediksi di dua sentra produksi padi. Penelitian berupa desk study dengan mengambil contoh kasus di Kabupaten Indramayu dan Cianjur, Jawa Barat. Penelitian dilakukan dengan empat tahapan. Tahap pertama adalah pengumpulan data curah hujan dan peta informasi Stasiun Curah Hujan dan Klimatologi di setiap kecamatan menggunakan kombinasi input Anomali SST Nino3-4 dan DMI, data yang digunakan tahun 1990 - 2010( Yayan Apriana 2015).

Penelitian ini Berjudul "Perdiksi curah hujan di wilayah makassar menggunakan metode Wavelet Dan Neural network". pelatihan ini bertujuan untuk memprediksi sekaligus memvalidasi antara data real dan data prediksi intensitas curah hujan harian pada tahun 2009, 2010, dan 2011. Khusus untuk tahun 2012, tidak diperoleh data real dari penelitian sebelumnya maupun dari BMKG setempat( Indrabayu 2011).

\section{METODE PENELITIAN}

\subsection{Prosedur Penelitian.}

Tahap awal yang dilakukan adalah melakukan survey untuk menentukan lokasi, Tahap kedua dilakukan setelah lokasi telah ditentukan dimana dalam tahap ini dilakukan wawancara terhadap beberapa petani, Tahap berikutnya adalah mengamati semua data yang berhubungan dengan pertanian di wilayah atau lokasi yang telah ditentukan. Pengambilan data iklim dan data pertanian, Tahap berikutnya mencari solusi dari permasalahan penentuan jadwal tanam dengan melakukan prediksi menggunakan jaringan syaraf tiruan untuk menentukan produktivitas padi yang optimal, dan Dari hasil prediksi diperoleh waktu yang baik untuk mendapatkan produktivitas padi yang optimal yang selanjutnya diputuskan rekomendasi jadwal tanam.

\subsection{Tempat dan Waktu Penelitian}

Penelitian ini dilaksanakan di kantor BMKG sul-sel dan di kantor dinas pertanian Bulukumba dan dilakukan selama 6 bulan dimulai dari bulan Maret 2018 sampai bulan agustus 2018 .

\subsection{Data Penelitian}

Data pengamatan yang digunakan dalam penelitian ini merupakan data sekunder yang diperoleh dari hasil pengukuran data unsur-unsur iklim di Kabupaten Bulukumba oleh Badan Meteorologi Klimatologi dan Geofisika (BMKG) tahun 2008-2017. Data pertanian untuk jumlah produktivitas padi diambil dari data sekunder pada kantor Dinas Pertanian Kabupaten Bulukumba.

\subsection{Blok Diagram Perencanaan Sistem}

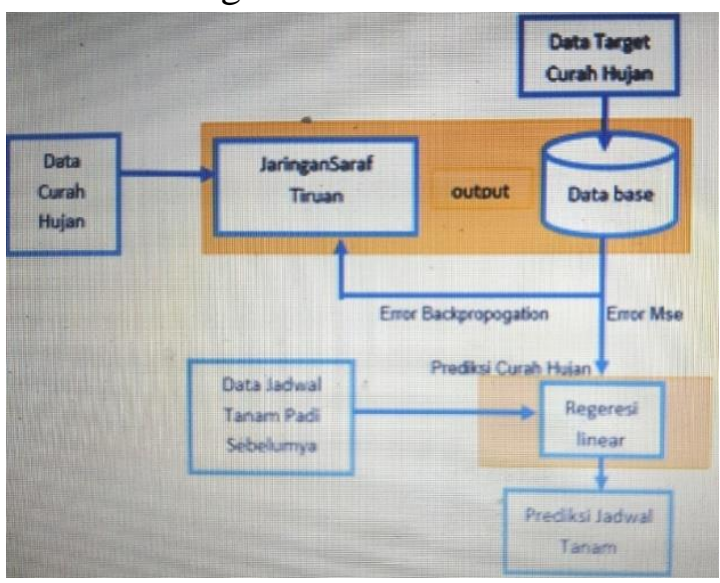

Gambar 1. Blok Diagram Perencanaan Syistem 
1) Data curah hujan

Data curahhujan yang aktual yang digunakan dan akan di imput kedalam Aplikasi Jaringan saraf tiruan, data ini diambil dari bmkg dan di imput dengan menggunakan microsof exel.

2) Jaringan saraf tiruan Jarngan safar tiruan digunakan untuk mentraining data curah hujan aktual yang akan meghasilkan ouput dan akan di input kedalam data base.

3) Data base

Data base Mendapatkan dua imputan data yang pertama yaitu data curah hujan yang telah ditraining, dan data target curah hujan, dari data base akanmenghasilkan dua output yaitu,data error MSE yang akan diteruskan menjadi prediksi curah hujan, dan data error Beckpropagation yang akan dikembalikan ke dalam jaringan saraf tiruan untuk diproses kembali.

4) Regeresi Linear

Regeresi linear digunakan untuk mengubah dua imputan yaitu imputan data prediksi curah hujan dan data jadwal tanam padi sebelumnya, dua data ini akan di proses yang akan menghasilkan output berupa prediksi jadwal tanam padi.

\section{HASIL DAN PEMBAHASAN}

4.1. Implementasi Sistem

1) Perancangan Sistem

Gambaran umum sistem yang akan dikembangkan pada penelitian ini dapat dilihat pada gambar 2 .

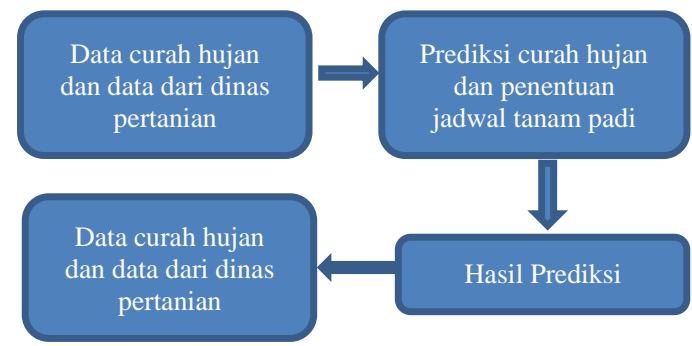

Gambar 2. Gambaran umum system

Pada gambar 2, gambaran umum sistem yang dibuat adalah:

a. Data yang dimasukkan dalam bentuk excel (*.xls). Data curah hujan yang digunakan adalah data curah hujan selama 10 tahun. Data yang kemudian dinormalisasi oleh sistem ke dalam nilai antara 0 dan 1 .

b. Data yang sudah dinormalisasi kemudian diolah oleh sistem dengan menggunakan metode jaringan saraf tiruan. Dari proses ini menghasilkan keluaran berupa bobot terbaik yang dihasilkan dari hasil training data.

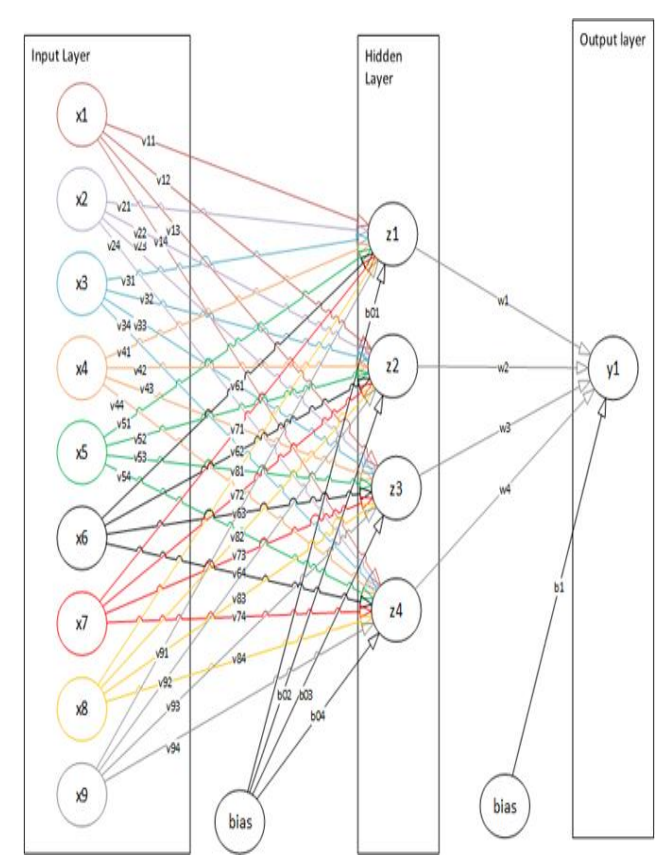

Gambar 3. Arstitektur JST Backpropagation 
Bahwa pada gambar 3 terdapat 9 data ke input layer pada masing- masing bulan dalam data training, 1 hidden layer 4 node, dan menegluarkan hasil 1 output layer untuk prediksi tiap bulannya, sehingga dilakukan 12 kali sesuai jumlah bulan yang akan diprediksi tiap tahun.

2) Proses Prediksi Iklim dengan JST Backpropagation

Data yang digunakan untuk melakukan prediksi curah hujan adalah data curah hujan bulanan di Kabupaten Bulukumba selama 10 tahun.

a. Normalisasi Data

Data curah hujan bulanan yang diperoleh dari BMKG dinormalisasi ke bilangan antara 0 dan 1 dengan menggunakan persamaan:

$$
x^{\wedge^{\prime}}=(0,8(x-a)) /(b-a)+0,1
$$

a adalah data minimum, $b$ adalah data maksimum yang akan dinormalisasi dan $\mathrm{x}^{{ }^{\prime}}$ adalah data yang telah dinormalisasi.

Dari hasi normalisasi ini akan akan diperoleh data bialangan terkecil 0,1 dan bilangan terbesar 0,9. Data ini disesuaiakan dengan fungsi aktivasi yang digunakan pada jaringan saraf tiruan backpropagation yaitu fungsi sigmoid.

\section{b. Data Training}

Data yang sudah dinormalisasi ditraining dengan jaringan syaraf tiruan backpropagation. Proses training dilakukan dengan mengambil 9 tahun sebagai data penginputan, 1 hidden layer dengan 4 node dan menghasilkan satu nilai output.

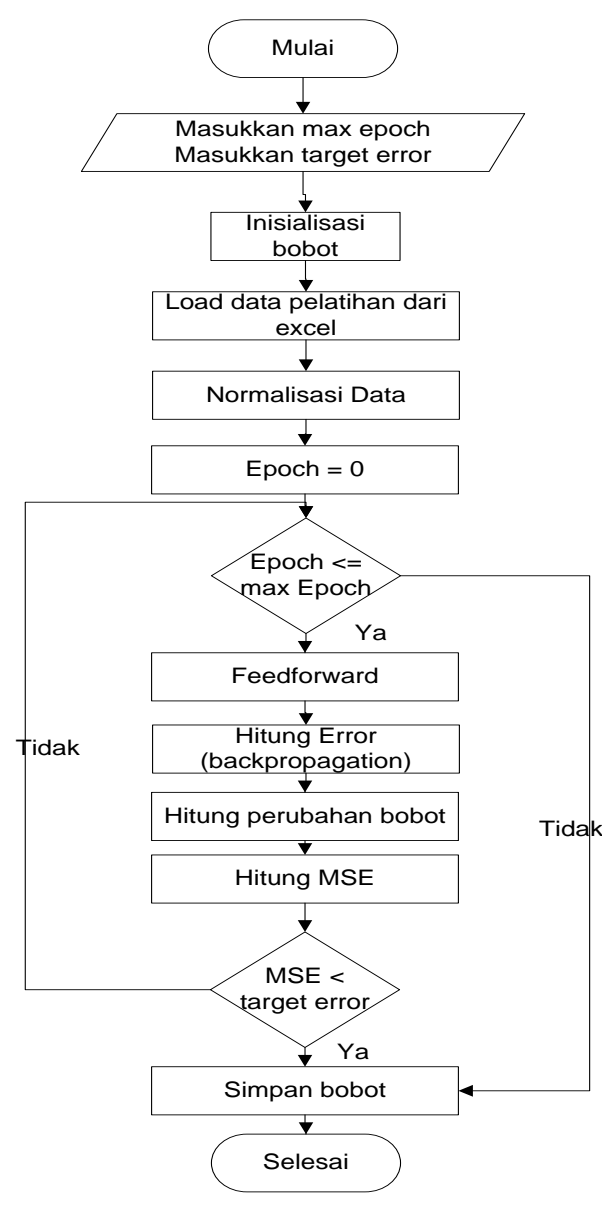

Gambar 4. Flowchart program pelatihan jaringan saraf tiruan (Dini, 2010)

Langkah awal yang dilakukan adalah menentukan target error dan batas epoch maksimum. Selanjutnya sistem memilih bilangan acak yang kecil (bilangan antara 0 dan 1) sebagai bobot awal dalam proses training. Memasukkan data curah hujan bulan dari file excel (*.xls)

Data yang telah dimasukkan, dinormalisasi dan training dengan jaringan saraf tiruan backpropogation. Proses training data dilakukan sampai nilai error yang diperoleh lebih kecil dari nilai error yang dimasukkan atau jumlah epoch sama dengan nilai epoch yang diinput diawal. Setelah proses training selesai maka akan diperoleh nilai bobot terbaik. Nilai bobot 
terbaik tersebut kemudian disimpan dan dilakukan proses prediksi.

\section{c. Data Pengujian}

Data pengujian digunakan untuk prediksi hujan dengan melakukan langkahlangkah berikut.

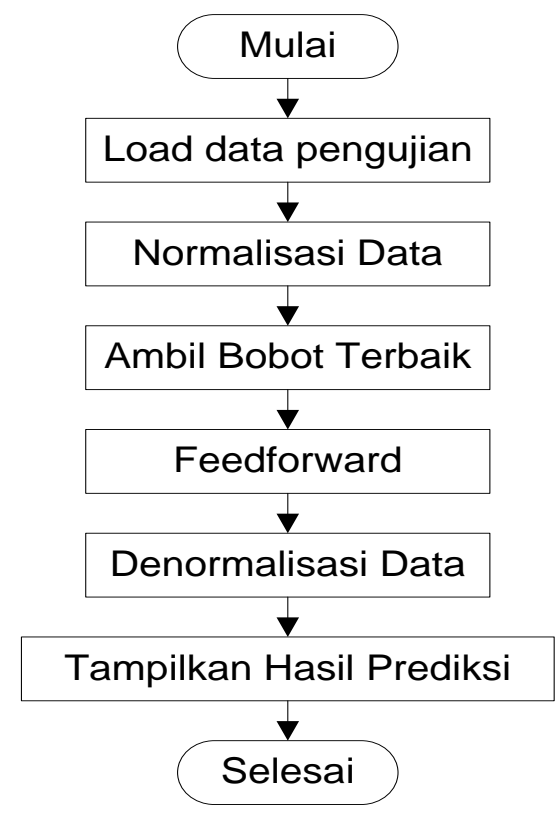

Gambar 5. Flowchart program pengujian jaringan saraf tiruan

(Dini, 2010)

Mengambil data pengujian kemudian dinormalisasi dengan menggunakan rumus berikut:

$$
x=\left(\left(x^{\prime}-0,1\right)(b-a)\right) / 0,8+a
$$

a adalah data minimum, $b$ adalah data maksimum yang akan dinormalisasi dan $\mathrm{x}$ adalah data yang telah didenormalisasi.

Data pengujian yang sudah dinormalisasikan disimulasikan dengan jaringan saraf tiruan dengan mengambil bobot yang terbaik pada proses training. Data hasil simulasi kemudian didenormalisasikan untuk memperoleh data curah hujan hasil prediksi.

\subsection{Pengujian Sistem}

Interface sistem merupakan bagian dari aplikasi sistem prediksi produktivitas padi dan rekomendasi jadwal tanam diuji dengan menggunakan teknik black box yakni menguji setiap fungsi yang ada pada aplikasi untuk mengetahui fungsi-fungsi dalam aplikasi dapat berjalan dengan baik. Terdapat beberapa antarmuka dalam sistem yang akan diuji yaitu antar muka data curah hujan, normalisasi data, data training, proses dan hasil prediksi curah hujan serta antar muka prediksi produktivitas padi dan rekomendasi jadwal tanam.

1) Antarmuka Data Curah Hujan

Pada antarmuka Data Curah Hujan, terdapat beberapa fungsi tombol yang tampil yaitu load data, hasil isi tabel. Terdapat juga Input label dalam antar muka ini yaitu batas error yang menentukan berapa persen kesalahan yang dapat ditoleransi dalam menjalankan fungsi aplikasi sistem prediksi ini. Label iterasi berfungsi untuk memberikan batas maksimum iterasi dalam proses training data. Label fungsi terakhir pada antarmuka ini adalah label MSE yaitu label yang berfungsi untuk menentukan batas error rata-rata dari perhitungan data training, semakin besar MSE maka semakin tidak akurat data yang dihasilkan sebaliknya semakin kecil nilai MSE maka data prediksi yang dihasilkan semakin baik. Hasil pengujian semua fungsi dalam antarmuka ini baik fungsi tombol dan fungsi label menunjukkan hasil yang optimal. Dapat terlihat dari gambar dibawah ini fungsi menunjukkan bahwa fungsi tombol load data curah hujan bulanan selama beberapa tahun terlihat diinput dengan baik oleh sistem dan menampilkan data secara teratur untuk tiap bulannya. 
Tabel 1. Data curah hujan tahun 2008-2017 Kabupaten Bulukumba

\begin{tabular}{|c|c|c|c|c|c|c|c|c|c|c|c|c|}
\hline un & fet & & & & & & & & & & & \\
\hline 2008 & 238 & 67 & 162 & 207 & 520 & 246 & 77 & 34 & 35 & 63 & 222 & 171 \\
\hline 2009 & 172 & 105 & 103 & 172 & 245 & 47 & 112 & 0 & 1. & 0 & 0 & 0 \\
\hline 2010 & 203 & 116 & 34 & 220 & 501 & 689 & 473 & 283 & 217 & 185 & 174 & 173 \\
\hline 2011 & 124 & 127 & 185 & 329 & 343 & 70 & 35 & 1 & 41 & 177 & 78 & 176 \\
\hline 2012 & 57 & 127 & 111 & 30 & 362 & 111 & 146 & 15 & 2 & 5 & 39 & 197 \\
\hline 2013 & 116 & 138 & 58 & 168 & 425 & 432 & 416 & 25 & 0 & 12 & 143 & 243 \\
\hline 2014 & 162 & 86 & 307 & 40 & 323 & 247 & 212 & 188 & 5 & 0 & 8 & 174 \\
\hline 2015 & 79 & 149 & 131 & 253 & 174 & 147 & 7 & 0 & 0 & 0 & 0 & 366 \\
\hline 2016 & 102 & 266 & 254 & 259 & 172 & 156 & 96 & 26 & 63 & 379 & 124 & 148 \\
\hline 2017 & 72 & 200 & 77 & 79 & 288 & 443 & 434 & 0 & 97 & 44 & 113 & 0 \\
\hline
\end{tabular}

Sumber : Badan Meteorologi Klimatologi dan Geofisika

2) Antarmuka Normalisasi Data

Antarmuka ini menunjukkan sejumlah fungsi tombol dan label untuk melakukan pengaturan normalisasi terhadap data yang dimasukkan pada antarmuka data Curah Hujan. Antarmuka ini berfungsi untuk melakukan konversi nilai data menjadi nilai bilangan antara 0 dan 1 sehingga dapat diproses dalam perhitungan tahap selanjutnya yaitu pada simulasi jaringan saraf tiruan. Fungsi tombol normalisasi mengambil data dari antarmuka curah hujan yang telah dimasukkan ke dalam tabel antarmuka kemudian melakukan konversi menjadi nilai bilangan antara 0 dan 1 . Hal ini dapat terlihat jelas dalam tabel yang disajikan bahwa fungsi tombol berjalan dengan baik, dengan menampilkan hasil data konversi pada antarmuka. Fungsi tombol hapus normalisasi dapat menghapus data hasil konversi. Pada antarmuka ini terdapat dua fungsi label yaitu fungsi label Nilai MAX dan Nilai MIN. Kedua fungsi label tidak dapat diinput secara manual namun nilai ini muncul secara otomatis ketika data dinormalisasi. Kedua nilai ini menunjukkan nilai maksimum dan nilai minimum dari keseluruhan data yang diproses. Terlihat fungsi ini berjalan secara optimal dengan menampilkan hasil yang benar sesuai dengan nilai maksimum dan minimum yang muncul pada tabel antamuka normalisasi.

Tabel 3. Data normalisasi curah hujan tahun 2008-2017

\begin{tabular}{|r|r|r|l|l|l|l|l|r|r|r|r|r|}
\hline Tahun & Jan & \multicolumn{1}{l}{ Peb } & Mar & Apr & Mei & Jun & Jul & Ags & Sep & Okt & Nop & Des \\
\hline 2008 & 0,253 & 0,39 & 0,869 & 0,833 & 0,736 & 0,135 & 0,493 & 0,75 & 0,861 & 0,449 & 0,488 & 0,299 \\
\hline 2009 & 0,972 & 0,582 & 0,361 & 0,972 & 0,025 & 0,184 & 0,354 & 0,1 & 0,11 & 0,1 & 0,1 & 0,1 \\
\hline 2010 & 0,392 & 0,795 & 0,75 & 0,427 & 0,263 & 0,9 & 0,174 & 0,216 & 0,936 & 0,406 & 0,193 & 0,301 \\
\hline 2011 & 0,678 & 0,009 & 0,406 & 0,029 & 0,835 & 0,721 & $9 E+09$ & 0,11 & 0,522 & 0,524 & 0,604 & 0,304 \\
\hline 2012 & 0,287 & 0,009 & 0,244 & 0,309 & 0,33 & 0,244 & 0,104 & 0,655 & 0,221 & 0,552 & 0,302 & 0,329 \\
\hline 2013 & 0,795 & 0,222 & 0,398 & 0,531 & 0,88 & 0,652 & 0,887 & 0,758 & 0,1 & 0,324 & 0,774 & 0,382 \\
\hline 2014 & 0,869 & 0,486 & 0,864 & 0,441 & 0,628 & 0,245 & 0,385 & 0,737 & 0,552 & 0,1 & 0,882 & 0,302 \\
\hline 2015 & 0,714 & 0,044 & 0,45 & 0,907 & 0,193 & 0,215 & 0,772 & 0,1 & 0,1 & 0,1 & 0,1 & 0,525 \\
\hline 2016 & 0,251 & 0,341 & 0,017 & 0,569 & 0,972 & 0,208 & 0,589 & 0,868 & 0,449 & 0,806 & 0,678 & 0,272 \\
\hline 2017 & 0,942 & 0,221 & 0,493 & 0,714 & 0,768 & 0,865 & 0,872 & 0,1 & 0,7 & 0,853 & 0,464 & 0,1 \\
\hline
\end{tabular}

\section{3) Antarmuka Data Training}

Pada antarmuka ini dapat dijelaskan bahwa fungsi dari antarmuka adalah melakukan training pada data yang telah dinormalisasi. Pada fungsi list box "Dari Tahun" kita dapat memilih data pertama tahun tertentu. Pada list box ini terdapat beberapa tahun yang bisa dipilih sebagai data awal. Pada list box "sampai" kita memilih tahun terakhir yang dipilih untuk pengolahan data training. Fungsi tombol "ambil data" adalah mengambil data dari tahun awal sampai tahun terakhir yang dipilih pada list box "dari tahun" dan list box "sampai". Semua fungsi tombol dan list box ini berfungsi dengan baik karena dapat menampilkan hasil sesuai dengan data pada tabel hasil data normalisasi.

\section{4) Proses dan Hasil Prediksi Curah Hujan}

Pada proses perhitungan jaringan saraf tiruan untuk melakukan prediksi curah hujan hal pertama yang dilakukan adalah melakukan inisialisasi bobot awal. Bobot awal ini berasal dari bilangan acak antara bilangan 0 dan 1. Setelah itu dilakukan proses training data dengan algoritma backpropagation. Label hasil keluaran 
menunjukkan hasil proses training data sesuai dengan nilai bobot terbaik. Hasil keluaran bobot terbaik ini.

Tabel 4. Data prediksi curah hujan tahun 2018,2019, dan 2020

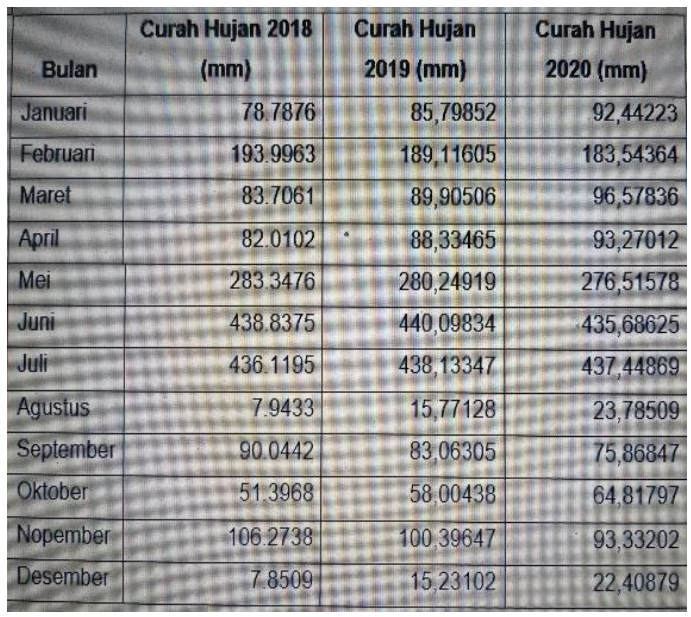

5) Rekomendasi Jadwal Tanam

Pada antarmuka ini dilakukan prediksi jadwal tanam padi yang selanjutnya dijadikan dasar dalam penentuan jadwal tanam padi. Pada tombol "Ambil Data", dilakukan proses pengambilan data hujan bulanan yang telah diprediksi. Dengan menggunakan data prediksi curah hujan maka dilakukan prediksi penentuan jadwal tanam dan panen padi. Kesimpulan penentuan masa tanam dilakukan berdasarkan prediksi curah hujan yang paling mendekati dan parameter penentuan jadwal tanam padi dilakukan seacra perbulan dalam kurun waktu satu tahun.

\subsection{Pengujian dengan Data}

Pada bagian ini akan dilakukan pengujian model prediksi curah hujan degan membandingkan data preiksi curah hujan tahun 2017 dan data curah hujan aktual yang diperoleh dari kantor Badan Meteorologi Klimatologi dan Geofisika.
Tabel 5. Tabel perhitungan nilai error data curah hujan tahun 2017

\begin{tabular}{|r|r|r|r|r|r|}
\hline \multicolumn{1}{|c|}{$\mathrm{Yt}$} & \multicolumn{1}{c|}{$\overline{\mathrm{Yt}}$} & et & |et & \multicolumn{1}{c|}{ et 2 } \\
\hline 1 & 72 & 78 & -6 & 6 & 36 \\
\hline 2 & 200 & 193 & 7 & 7 & 49 \\
\hline 3 & 77 & 83 & -6 & 6 & 36 \\
\hline 4 & 79 & 82 & -3 & 3 & 9 \\
\hline 5 & 288 & 283 & 5 & 5 & 25 \\
\hline 6 & 443 & 438 & 5 & 5 & 25 \\
\hline 7 & 434 & 436 & -2 & 2 & 4 \\
\hline 8 & 0 & 7 & -7 & 7 & 49 \\
\hline 9 & 97 & 90 & 7 & 7 & 49 \\
\hline 10 & 44 & 51 & -7 & 7 & 49 \\
\hline 11 & 133 & 106 & 27 & 27 & 729 \\
\hline 12 & 0 & 7 & -7 & 7 & 49 \\
\hline jumlah & 1867 & 1854 & 13 & 89 & 1109 \\
\hline
\end{tabular}

Keterangan:

$$
\mathrm{e}_{\mathrm{t}}=\text { kesalahan peramalan curah }
$$

hujan

$$
\begin{gathered}
\mathrm{Y}_{\mathrm{t}}=\text { data curah hujan aktual } \\
\overline{\mathrm{Y}}_{\mathrm{t}}=\text { hasil prediksi curah hujan } \\
\text { MSE }=\frac{\sum_{t=1}^{n}\left(Y_{t}-\bar{Y}_{t}\right)^{2}}{n}=\frac{169}{12}=14,08333
\end{gathered}
$$

$$
\mathrm{RMSE}=\sqrt{ } \mathrm{MSE}=\sqrt{ } 14,08333=3,752777
$$

Berdasarkan perhitungan tersebut diperoleh nilai MSE untuk data curah hujan adalah sebesar 14,08333 dan untuk nilai RMSE adalah sebesar 3,752777.Dan dari hasil perhitungan diatas dapat disimpulkan bahwa nilai MSE dan nilai RMSE sangat baik sesuai dengan standar yang telah ditentukan.

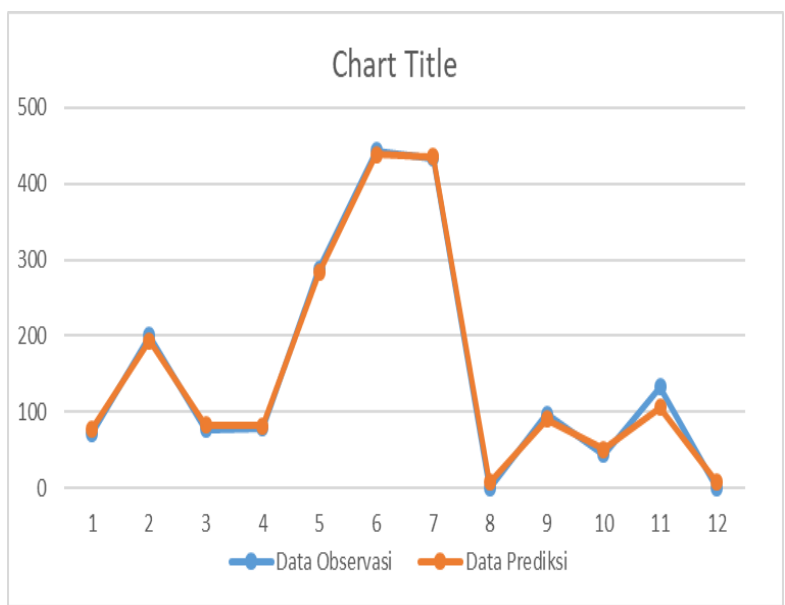

Gambar 6. Data curah hujan tahun 2017 
Dari gambar 6. dapat disimpulkan bahwa bobot curah hujan aktual dan data prediksi tahun 2017 tidak jauh berbeda.

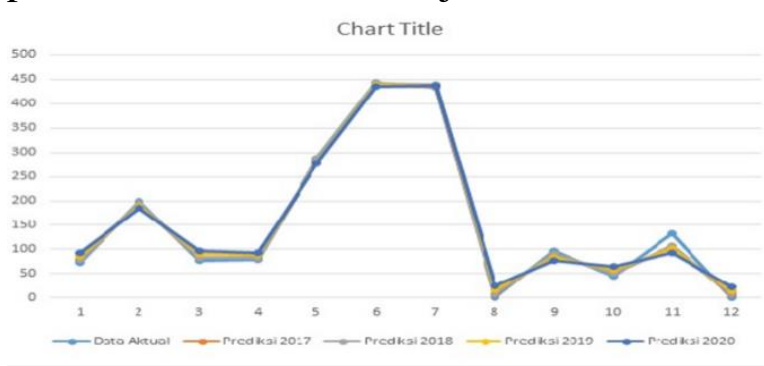

Gambar 7. Data curah hujan $2017,2018,2019,2020$

Dari gambar 7. dapat disimpulkan bahwa bobot curah hujan aktual dan data prediksi tahun 2017,2018,2019,2020 tidak jauh berbeda.

\section{SIMPULAN DAN SARAN}

\subsection{Kesimpulan}

Berdasarkan penelitian yang telah dilakukan, maka dapat diambil kesimpulan antara lain:

1) Hasil prediksi jadwal tanam padi maksimum diperoleh pada bulan Juni dengan memilih nilai tertinggi, Dan ditentukan jadwal tanam yang baik adalah pada bulan mei.

2) Pada prediksi curah hujan diperoleh nilai MSE sebesar 14,08333 dan nilai RMSE adalah sebesar 3,752777,Dinyatakan sangat baik sesuai dengan standar yang telah ditentukan.

3) Perubahan pola curah hujan sangat berpengaruh pada hasil produksi padi disuatu daerah terutama dengan lahan sawah yang hanya mengandalkan hujan ( Sawah tadah hujan ).

\subsection{Saran}

Program aplikasi ini tentunya belum dapat dikatakan sempurna, oleh beberapa saran yang perlu diperhatikan :

1) Mangembangkan sistem ini dengan memasukkan beberapa variabel antar lain suhu udara dan kelembapan tanah untuk melakukan proses prediksi jadwal tanam dan panen padi untuk mendapatkan hasil yang lebih akurat.

2) Melakukan perbaikan pada metode prediksi untuk mendapatkan hasil prediksi dengan nilai RMSE yang lebih kecil dari nilai 3,752777.

3) Melakukan pengambilan data curah hujan selain dari data dari BMKG.

4) Dapat menambahkan metode forward propagation dalam pengembangan penelitian ini.

\section{DAFTAR PUSTAKA}

Akhmad Fadholi,2013.Persamaan Regresi Prediksi Curah Hujan Bulanan Menggunakan Data Suhu dan Kelembapan Udara di Ternate. Stasiun Meteorologi Depati Amir, Pangkalpinang.

Andaru, S.G. 2009. Perancangan Program Aplikasi Prediksi Curah Hujan Dengan Metode Backpropagation. Skripsi. Program Ganda Teknik Informatika dan Matematika Universitas Bina Nusantara, Jakarta.

Annisa.M, 2013,Pertanian Padi Sebagai EkonomiI Lokal Kabupaten Bulukumba, Sulawesi Selatan Yang Berorientasi Ekspor, universitas negeri makassar.

Arifin, A. N., Halide, H., Hasanah, N. 2009. Prediksi Probabiliitas Produktivitas Tanaman Pangan di Kota Makassar 
Berbasis Iklim. Universitas Hasanuddin, Makassar.

Case, M., Fitrian, A., and Emily, S. 2009.

Climate Change in Indonesia, Implications for Human and Nature. Brandeis University.

Dainti Iga. 2016. Analisis Peluang Curah

Hujan untuk Penetapan Pola dan Waktu Tanam Serta Pemilihan Jenis Komoditi yang Sesuai. Jurnal Ilmiah Rekayasa Pertanian dan biosistem

Dini, O.M. 2010. Neural Network Implementation in Foreign Exchange Kurs Prediction. Skripsi. Universitas Gunadarma, Jakarta.

Eka Syafitri Andarini, Sri Wahyuningsih, Rito Goejantoro,2015. Prediksi Curah Hujan Kota Samarinda pada Tahun 2014 dengan Metode Filter Kalman. Universitas Mulawarman.

Faggin. F,.1991. VLSI Implementation of Neural Networks. Tutorial Notes, International Joint Conference on Neural Network, Seattle.

Fausett, Laurene. 1994. Fundamentals of Neural Networks. Prentice-Hall, Inc., New Jersey.

Haykin, S., 1999. Neural Network: A Comprehensive Foundation. PrenticeHall, Inc., New Jersey.

Indrabayu, Nadjamudin Harun,M. Saleh Pallu, Andani Achmad,2011. Prediksi curah Hujan diwilayah Makassar Dengan Menggunakan Metode Wavelet dan Neural Network. Universitas Hasanuddin, Makassar.

IPCC. 2007. Climate Change: The Physical Science Basis, Contribution of Working Group (WG) 1 to the Fourth Assessment Report of the (IPCC), Cambridge University Press, Cambridge, UK, and New York.

Woro Estiningtyas dan Muhammad Syakir. 2017. Pengaruh perubahan iklim terhadap produksi padi di lahan tadah hujan. Balai Besar Penelitian dan Pengembangan Pertanian, Jl. Tentara Pelajar No 1A Cimanggu Bogor. 